\title{
Assessment of the Impact of the Nile Flood on Food Chain in Lake Nasser-Egypt, with Special Reference to Turbidity
}

\author{
Talaat A. Salem¹, Adel Ali A. Mageed ${ }^{2}$ \\ ${ }^{1}$ National Water Research Center, Nile Research Institute, El-Qanater El-Khairiya, Egypt \\ ${ }^{2}$ National Institute of Oceanography and Fisheries, Cairo, Egypt \\ Email: adel_abdelmageed@yahoo.co.nz
}

How to cite this paper: Salem, T.A. and Mageed, A.A.A. (2021) Assessment of the Impact of the Nile Flood on Food Chain in Lake Nasser-Egypt, with Special Reference to Turbidity. Open Journal of Ecology, 11, 41-51.

https://doi.org/10.4236/oje.2021.111004

Received: November 14, 2020

Accepted: January 3, 2021

Published: January 6, 2021

Copyright () 2021 by author(s) and Scientific Research Publishing Inc. This work is licensed under the Creative Commons Attribution International License (CC BY 4.0).

http://creativecommons.org/licenses/by/4.0/

\begin{abstract}
This study aimed to assess the impact of the Nile flood with special reference to turbidity on the food chain in Lake Nasser water as one of the largest man-made lakes in Africa before the flood (BF) and after the flood (AF) seasons. To achieve that aim, subsurface water samples were collected from 11 sampling stations along the lake before and after the flood for analyzing the water turbidity, total suspended solids, and total phosphorus, as well as chlorophyll- $a$ and zooplankton to represent the food chain in the lake. Results showed an increase in water turbidity after the flood than that before the flood. Total suspended solids concentration displayed a similar trend as water turbidity. Chlorophyll-a concentration increased in AF all over the lake except at the entrance of the lake, as compared to the BF season. Zooplankton count was represented by copepods, cladocerans, and rotifers with the dominance of copepods in AF and rotifers in BF. The density of zooplankton was higher in the AF than the $\mathrm{BF}$ season. The negative impact of flood turbidity had appeared on crustacean organisms.
\end{abstract}

\section{Keywords}

Lake Nasser, Flood, Turbidity, Phytoplankton, Chlorophyll-a, Zooplankton

\section{Introduction}

Lake Nasser provides an important source of water for humans, livestock, agriculture, the generation of hydro-power, fish production, and eco-tourism. Lake Nasser is unique in its performance as it is located in a barren desert. The Nile flood originates from the Ethiopian plateau and flows once a year during late 
summer. It is characterized by its high turbidity as it carries a heavy load of sand, silt, and clay [1].

Planktons are microscopic organisms drifted by the water flow and are considered the main food web in the freshwater. They are constituted from phytoplankton and zooplankton. These organisms are crucial to life in the aquatic environment because they are considered the base of the food chain. The qualitative and quantitative abundance of the phytoplankton and zooplankton is significantly associated with current water quality conditions. So, the abundance and biodiversity of the planktons serve as an ecological indicator of the aquatic environment due to their quick response to any changes in the environmental factors of the aquatic systems [2] [3]. In Lake Nasser, the planktons are distributed and influenced by many factors such as flood events, turbidity, water levels, as well as other physicochemical factors. For instance, floods promote exchanges in water, sediments, organic matters, nutrients, and living organisms between the main river and the different floodplain units [4]. The fluctuations in the quantity of floodwaters from a year to another in the Nile are the most important factor affecting the abundance and community composition of organisms in the reservoir ecosystem [5].

High loads of turbidity may limit phytoplankton photosynthesis; thereby restricting the biomass development (chlorophyll-a) and subsequently, zooplankton diversity and density [6] [7]. Therefore, this research is conducted to recognize and assess the impact of the Nile flood with special reference to turbidity on the food chain in Lake Nasser.

\section{Materials and Methods}

High Aswan Dam Reservoir was created after the construction of the High Dam between 1958 and 1971. The reservoir is subtropical, divided into two parts with the majority of it belonging to the Egyptian side (extends for about $350 \mathrm{~km}$ between $22^{\circ} 00^{\prime}$ to $23^{\circ} 58^{\prime} \mathrm{N}$ and $31^{\circ} 30^{\prime}$ to $33^{\circ} 15^{\prime} \mathrm{E}$ ) representing about $83 \%$ of the surface area of the reservoir, known as Lake Nasser and the rest belonging to the Sudanese territories (extends for about $150 \mathrm{~km}$ ), known as Lake Nubia. The samples were collected from the subsurface water $(50 \mathrm{~cm})$ at eleven stations along the main channel of Lake Nasser during May before the flood season (BFS) and during October post the flood season (PFS) as in Table 1 and Figure 1.

Two litters water sampler was used to collect the water samples from 11 sampling stations along the lake. These samples were kept in cleaned plastic bottles for the analysis of turbidity, total suspended solids (TSS) and total phosphorus (TP) according to [8]. The food chain was represented by Chlorophyll- $a$ (phytoplankton) and zooplankton.

Chlorophyll-a (Chl. a) was measured by filtering of known volume (about 200 $\mathrm{ml}$ ) of water sample immediately after collection onto GF/F paper. The filters were extracted in $90 \%$ hot methanol and measured at the different wavelengths using a spectrophotometer. Zooplankton was carried out by a vertical tow from 


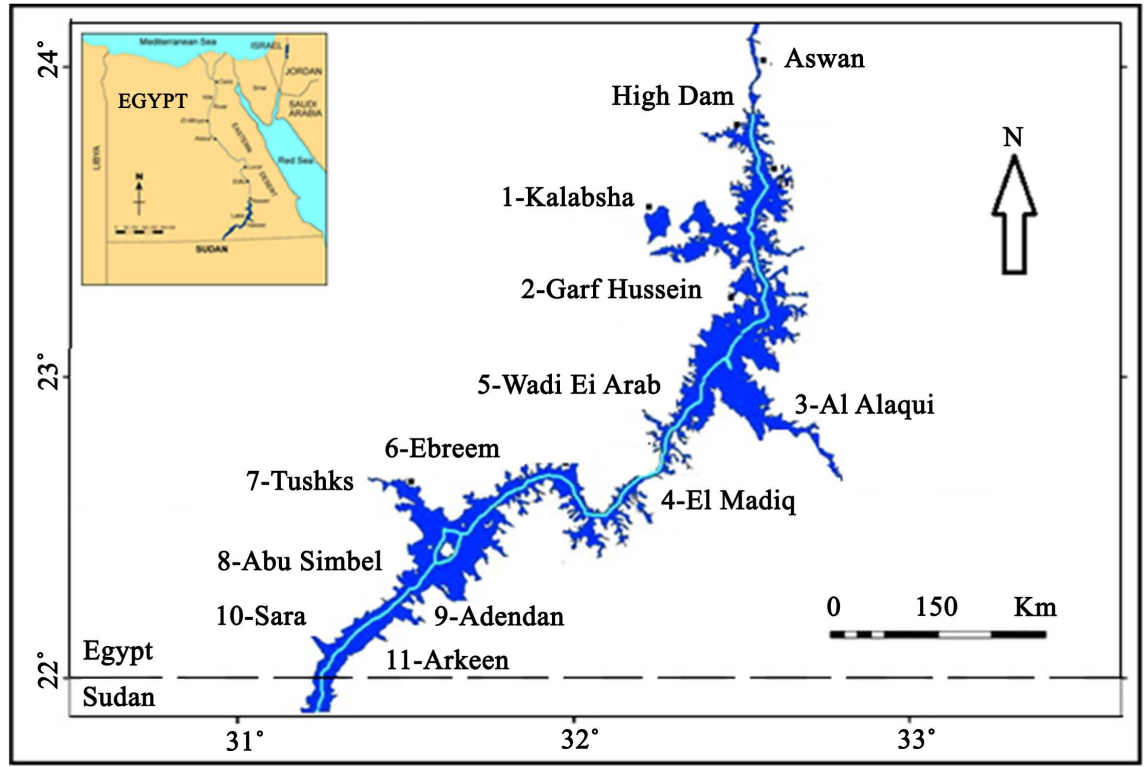

Figure 1. Sampling stations along Lake Nasser during the study period.

Table 1. Sampling stations description along Lake Nasser.

\begin{tabular}{lccc}
\hline \multirow{2}{*}{ Stations Name } & Km Up Stream & \multicolumn{2}{c}{ Position } \\
\cline { 2 - 4 } & Aswan High Dam & Latitude (N) & Longitude (E) \\
\hline 1. Kalabsha & 41 & $23^{\circ} 36^{\prime} 52^{\prime \prime}$ & $32^{\circ} 52^{\prime} 06^{\prime \prime}$ \\
2. Garf Hussain & 80 & $23^{\circ} 12^{\prime} 20^{\prime \prime}$ & $32^{\prime} 46^{\prime \prime}$ \\
3. El Alaki & 95 & $23^{\circ} 06^{\prime} 15^{\prime \prime}$ & $32^{\circ} 45^{\prime} 55^{\prime \prime}$ \\
4. El Madeek & 130 & $22^{\circ} 54^{\prime} 37^{\prime \prime}$ & $32^{\circ} 36^{\prime} 01^{\prime \prime}$ \\
5. Wadi El Arab & 171 & $22^{\circ} 43^{\prime} 25^{\prime \prime}$ & $32^{\circ} 27^{\prime} 28^{\prime \prime}$ \\
6. Ebreem & 228 & $22^{\circ} 39^{\prime} 28^{\prime \prime}$ & $31^{\circ} 59^{\prime} 02^{\prime \prime}$ \\
7. Tushka & 247 & $22^{\circ} 26^{\prime} 4^{\prime \prime}$ & $31^{\circ} 49^{\prime} 07^{\prime \prime}$ \\
8. Abu Simbel & 281 & $22^{\circ} 19^{\prime} 23^{\prime \prime}$ & $31^{\circ} 37^{\prime} 31^{\prime \prime}$ \\
9. Adendan & 307 & $22^{\circ} 12^{\prime} 04^{\prime \prime}$ & $31^{\circ} 28^{\prime} 54^{\prime \prime}$ \\
10. Sara & 325 & $22^{\circ} 04^{\prime} 44^{\prime \prime}$ & $31^{\circ} 22^{\prime} 10^{\prime \prime}$ \\
11. Arkeen & 333 & $22^{\circ} 01^{\prime} 44^{\prime \prime}$ & $31^{\circ} 21^{\prime} 14^{\prime \prime}$ \\
\hline
\end{tabular}

$2 \mathrm{~m}$ to the surface, with a plankton net $55 \mu \mathrm{m}$ mesh size. All samples were immediately fixed with $4 \%$ formalin. In the laboratory, the samples were examined, identified, and counted according to [9]-[17].

\section{Results and Discussion}

Lake Nasser, as one of the largest man-made lakes in Africa, is considered the main source of drinking and irrigation in Egypt, in addition to constitutes a very important sector in the Egyptian fisheries, both for significant total catch and for a large number of economically important fish species. Fish catch of Lake Nasser reached 19,751 tons during 2017 [18], so the study of its food chain became very important. The lake has prevalent lacustrine characteristics in front of the High Dam and riverine near the Sudan border, in addition to the transition zone 
in-between [5] [19].

It is worth mentioning that the water clarity for any waterbody is influenced by three variables, namely algal biomass (chlorophyll-a), non-algal suspended sediments (like silt and clay) and colored dissolved organic compounds that originated from humus substances [20] [21]. This means that the water turbidity or suspended solids values in Lake Nasser are controlled by these variables. Figure 2 shows that the water turbidity values ranged between $1.70-10.10$ NTU before the flood, while it ranged from 1.99 - 23.00 NTU after the flood. It is known that the sources of water turbidity in Lake Nasser may be autochthonous or allochthonous. Autochthones source occurs in the northern part due to the increase in primary productivity [22]. Elevated turbidity values at the southern stations in October (AF season) could be stemmed mostly from the flood water (allochthonous source) that loaded with suspended inorganic matters (silt and clay) at these stations [23]. The flood impact reached to Tushka area coming from Lake Nubia (Sudan), where the water turbidity decreased gradually from 23.00 NTU in the Arkeen area beside the Sudan border to only 3.47 NTU at Tushka after the flood period. These results are supported by the finding of [24], which found that the main channel sediments in the southern stations are mainly silty clay and clayey silt with a high percentage of clay.

Total suspended solids and turbidity complement each other, they are both influenced differently. TSS along the lake displayed a similar trend as water turbidity, and this was confirmed by the finding of [25]. They ranged between the lowest values at El Alaki $\left(2.0 \mathrm{mg} \cdot \mathrm{l}^{-1}\right)$ to the highest one at Arkeen $\left(13.0 \mathrm{mg} \cdot \mathrm{l}^{-1}\right)$ in the BF season and between $3.0 \mathrm{mg} \cdot \mathrm{l}^{-1}$ (at most of the northern stations) to 28.0 mg. $\mathrm{l}^{-1}$ (at Arkeen) in AF season (Figure 3). The impact of increasing the total

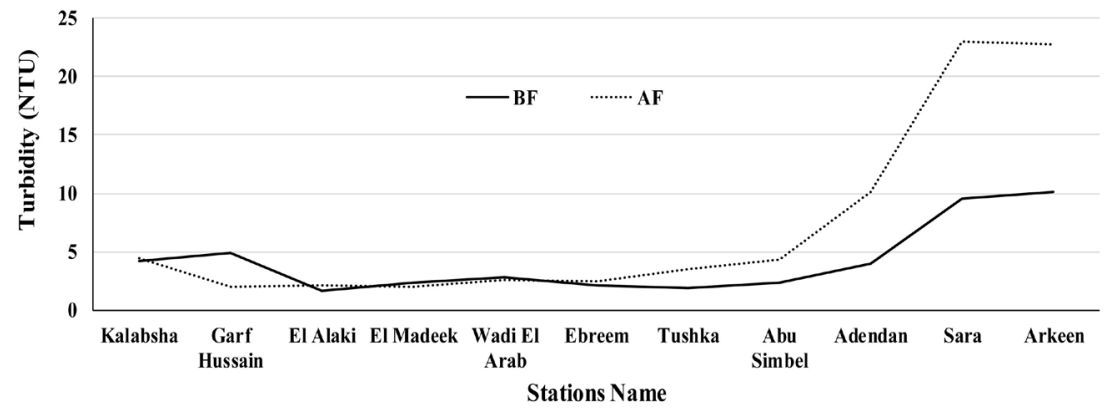

Figure 2. Turbidity (NTU) values before and after flood seasons at Lake Nasser.

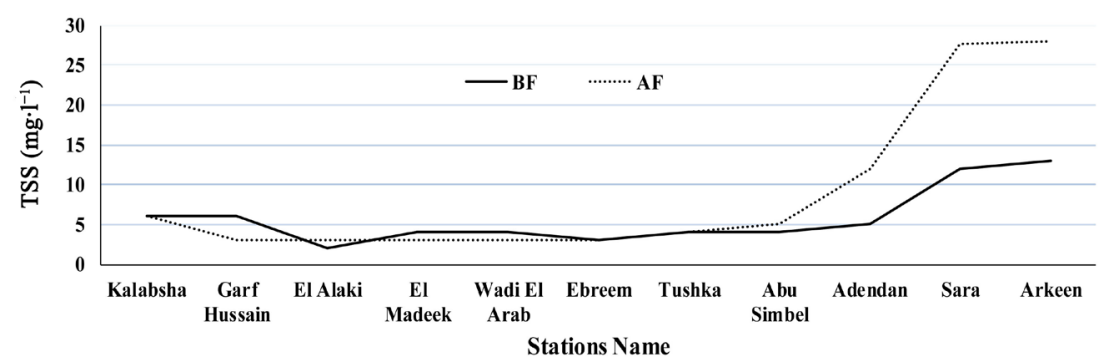

Figure 3. Total suspended solids $\left(\mathrm{mg} \cdot \mathrm{l}^{-1}\right)$ at Lake Nasser before and after flood seasons. 
suspended solids (TSS) on the biomass of phytoplankton (Chlorophyll-a) appeared more pronounced at the stations near the border with Sudan, especially in AF season. This can affect the abundance and community composition of phytoplankton and zooplankton species by damaging the primary production, thereby the availability of food supply for the aquatic organisms in the lake water [26]. [27] pointed out that some sources of suspended matters like that resulting from sediment resuspension had a great impact on the freshwater organisms by affecting their ecosystem structure and function.

Total phosphorus concentration varied from $0.03 \mathrm{mg} \cdot \mathrm{l}^{-1}$ to $0.06 \mathrm{mg} \cdot \mathrm{l}^{-1}$ (average $0.05 \mathrm{mg} \cdot \mathrm{l}^{-1}$ ) during $\mathrm{BF}$ season, while it ranged from $0.08 \mathrm{mg} \cdot \mathrm{l}^{-1}$ to $0.12 \mathrm{mg} \cdot \mathrm{l}^{-1}$ (average $0.09 \mathrm{mg} \cdot \mathrm{l}^{-1}$ ) during AF season (Figure 4). It is noted that phosphate concentration recorded with increasing values in AF season neared to double values in BF season. Also, it showed a decreasing trend northward. The total phosphorus enters the lake in particulate form or is associated with the suspended solids during the flood. Most of the phosphorus concentration is removed from the water column to the lake bottom by sedimentation [28], while the remaining fraction is uptake by the biological activities through the photosynthesis process.

The concentration of chlorophyll- $a$ is considered as a proxy for phytoplankton standing crop [29] [30]. Its range was 2 - $32 \mathrm{mg} \cdot \mathrm{l}^{-1}$ (average $9 \mathrm{mg} \cdot \mathrm{l}^{-1}$ ) and 4 - 40 $\mathrm{mg} \cdot \mathrm{l}^{-1}$ (average $14 \mathrm{mg} \cdot \mathrm{l}^{-1}$ ) in $\mathrm{BF}$ and AF seasons, respectively (Figure 5). The maximum value was recorded at Abu Simbel in AF season, due to pushing the flood to nutrients and plankton. Chlorophyll-a concentration decreased at Sara and Arkeen $(\mathrm{r}=0.920, \mathrm{p}<0.001)$. The decline of Chlorophyll- $\mathrm{a}$ concentration at these two stations in AF season is mainly due to the high level of turbidity at these stations that can light-limit phytoplankton photosynthesis and subsequently reduce biomass development [6].

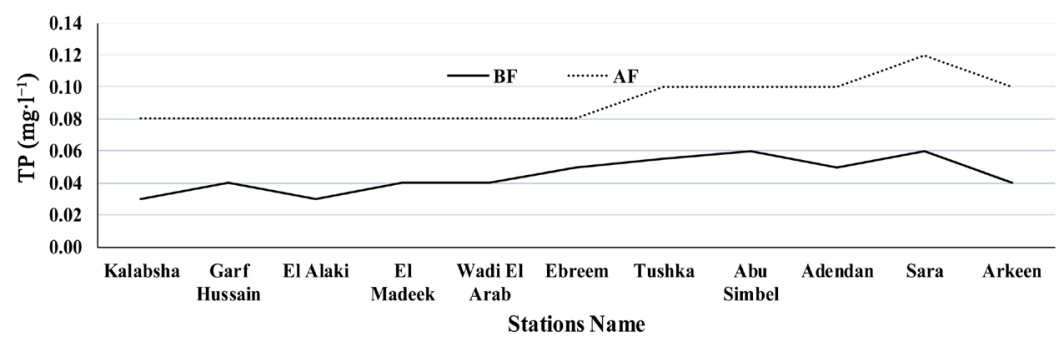

Figure 4. Total phosphorus (mg. $\mathrm{l}^{-1}$ ) at Lake Nasser stations before and after the flood seasons.

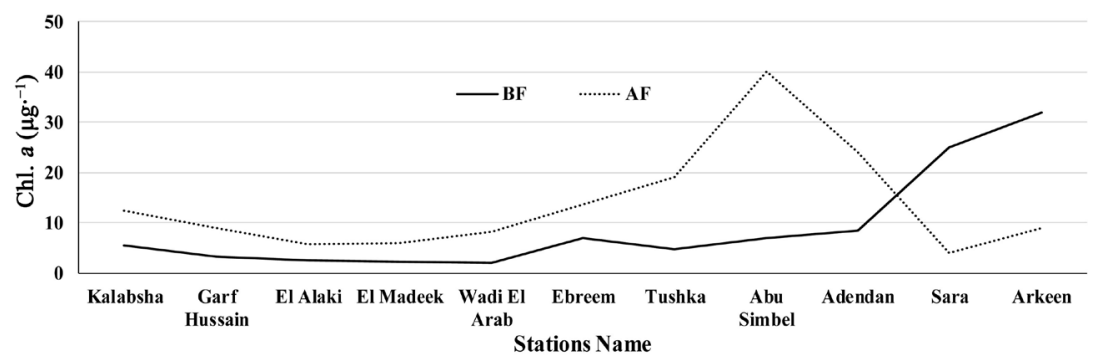

Figure 5. Chlorophyll-a $\left(\mu \mathrm{g} \cdot \mathrm{l}^{-1}\right)$ at Lake Nasser stations before and after flood seasons. 
Zooplankton in a lake, as an important part of the food chain in the aquatic ecosystem, is very sensitive to reflect the different environmental changes (such as nutrient, flood storm, turbidity, and TSS) and hence considered as a good indicator for changing in water quality variables [31] [32]. The community of zooplankton during the study is mainly composed of three taxonomic groups, including rotifers, cladocerans, and copepods. Studies by various investigators indicated that the zooplankton in the Lake Nasser community is represented by copepods, rotifers, and cladocerans [33] [34] [35].

Zooplankton density in Lake Nasser changes with the fluctuation in the lake water level, whereas it was varied according to the amount and the period of a flood each year [36]. The maximum standing crop of zooplankton appeared at the highest water level after the flood had entered $\left(37,606\right.$ org. $\left.\mathrm{m}^{-3}\right)$, while the minimum one was observed at a low water level before flood season (10,026 org. $\mathrm{m}^{-3}$ ) as in Figure 6. Zooplankton communities in Lake Nasser commonly increase in abundance after the flood than before flood season.

The changes in zooplankton during the two sampling seasons coincided with those of the phytoplankton and are concurrent with turbidity, as reported by [37] [38]. Besides, the competition among plankton species was intensified as a result of the turbidity of the water [39]. These results are similar to that obtained by [34] which concluded that the southern part (upstream) is richer in zooplankton than the northern one (downstream), as in Figure 6, and this coincided with the increased nutrient level in the water coming with the flood [40].

Lake Nasser water is classified as mesotrophic and good habitats for copepod organisms [34] [41] [42]. Copepods were the main dominant group of the zooplankton community in $\mathrm{AF}$, followed by cladocerans and rotifers, contributing $38.04 \%, 37.21 \%$, and $24.75 \%$ of the total zooplankton count, while these contributing in BF $34.78 \%, 28.44 \%$ and $36.78 \%$ of the total zooplankton count, respectively. It was correlated positively with turbidity $(r=0.644$ and $p<0.05)$. The zooplankton distribution showed the dominance of crustaceans (Copepoda and Cladocera) on rotifers at the three parts of the lake after the flood, while an opposite trend occurred before the flood. They had positively correlated with turbidity ( $\mathrm{r}=0.644, \mathrm{p}<0.05$ for copepods, and $\mathrm{r}=0.453, \mathrm{p}>0.05$ for cladocerans).

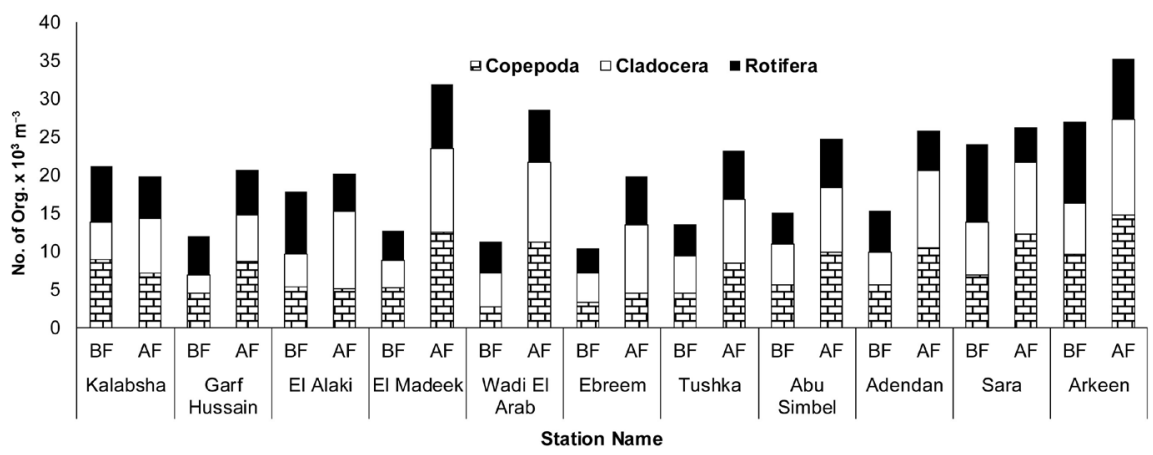

Figure 6. Distribution of zooplankton organisms (org. $\mathrm{m}^{-3}$ ) recorded at Lake Nasser stations before and after flood seasons. 
All the recorded crustaceans increased in the number of organisms by the turbidity of flood at the riverine part of the lake (Sara and Arkeen). For rotifers, most species increased in counts by turbidity increases. Some rotifer species appeared only in turbid water after the flood season such as Brachionus calyciflorus, B. caudatus, Keratella tropica, and Polyarthra vulgaris (Table 2).

Large zooplankton organisms (adult copepods and cladocerans) increased after the flood season in counts more than the small zooplankton organisms (rotifers and juvenile stages) in comparison with before the flood period. Juvenile stages of copepods were negatively influenced by clay particles. High concentrations of suspended sediments might have negative effects on copepod recruitment in the field [43] [44]. They stated that the feeding efficiency of copepods on phytoplankton decreased in the presence of suspended sediments, thus potentially decreasing the copepod egg production rate (Figure 7).

Table 2. Occurrence of zooplankton species to total zooplankton number and to group number before flood and after flood seasons.

\begin{tabular}{|c|c|c|c|c|c|}
\hline \multirow[b]{2}{*}{ Group } & \multirow[b]{2}{*}{ Species } & \multicolumn{2}{|c|}{ BFS } & \multicolumn{2}{|c|}{ AFS } \\
\hline & & $\begin{array}{c}\text { To Total } \\
\text { zoopl. }\end{array}$ & $\begin{array}{c}\text { To } \\
\text { group }\end{array}$ & $\begin{array}{c}\text { To Total } \\
\text { zoopl. }\end{array}$ & $\begin{array}{c}\text { To } \\
\text { group }\end{array}$ \\
\hline \multirow{3}{*}{ Copepoda } & Mesocyclops ogunnus & * & ** & * & $* *$ \\
\hline & Thermocyclops neglectus & * & * & $* *$ & $* * *$ \\
\hline & Thermodiaptomus galebi & $* *$ & $* * * *$ & ** & $* * *$ \\
\hline \multirow{6}{*}{ Cladocera } & Alona rectangula & * & $*$ & * & * \\
\hline & Bosmina longirostris & * & $* * *$ & * & ** \\
\hline & Ceriodaphnia cornuta & * & $* *$ & * & ** \\
\hline & Chydorus sphaericus & 0 & 0 & * & * \\
\hline & Daphnia longispina & * & * & * & ** \\
\hline & Diaphanosoma excisum & $* *$ & $* * *$ & $* *$ & $* * *$ \\
\hline \multirow{18}{*}{ Rotifera } & Annuropsis fissa & * & * & 0 & 0 \\
\hline & Asplanchna priodonta & * & * & 0 & 0 \\
\hline & Brachionus calyciflorus & 0 & 0 & * & $* *$ \\
\hline & Brachionus caudatus & 0 & 0 & * & * \\
\hline & Brachionus falcatus & * & * & * & * \\
\hline & Brachionus patulus & * & * & * & $* *$ \\
\hline & Cephalodella catellina & * & * & 0 & 0 \\
\hline & Collotheca sp. & $* *$ & $* * *$ & * & $* *$ \\
\hline & Epiphanes sp. & * & * & 0 & 0 \\
\hline & Filina longiseta & * & * & * & $* *$ \\
\hline & Keratella cochlearis & $* *$ & $* * *$ & * & ** \\
\hline & Keratella procurva & * & $* *$ & * & * \\
\hline & Keratella tropica & 0 & 0 & * & * \\
\hline & Lecane luna & * & * & 0 & 0 \\
\hline & Monostyla bulla & 0 & 0 & * & * \\
\hline & Polyarthra vulgaris & 0 & 0 & * & * \\
\hline & Ptygura libera & 0 & 0 & * & * \\
\hline & Trichocera chattoni & * & * & 0 & 0 \\
\hline
\end{tabular}

Note: 0 , absent; ${ }^{*},>10 \%$; ${ }^{* *}, 10 \%-25 \%$; ${ }^{* *}, 25 \%-50 \%$; ${ }^{* * *}, 50 \%-75 \%$; ${ }^{* * * * *}, 75 \%-100 \%$. 

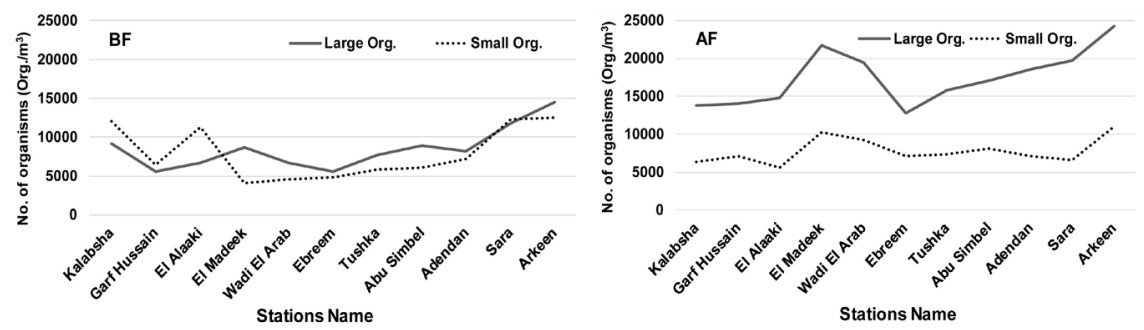

Figure 7. Spatial distribution of small and large zooplankton communities at Lake Nasser before the flood season (BF) and after flood season (AF). Small organisms (rotifers and juvenile stages); large organisms (adult copepods, and cladocerans).

Copepods are positively correlated with water turbidity in AF season, while cladocerans have occurred in habitats with low levels of turbidity in the BF season. This study recommended further environmental and biological monitoring that must be devoted to the lake about the planktonic organisms for increasing its fish production.

\section{Conclusions}

This paper concluded a great negative impact of turbidity on chlorophyll-a (as represented for phytoplankton biomass). For zooplankton, the highest standing crop was higher after the flood correlated with high turbidity, with the dominance of large zooplankton organisms after flood season than the small zooplankton organisms. The negative impact of flood turbidity had appeared on crustacean organisms.

It is often difficult to distinguish the effects of turbidity in the field from other effects of water such as nutrient loading or advection. Future studies need to assess the impact of mineral turbidity on the structure of freshwater plankton communities for increasing the fish production of the lake.

\section{Conflicts of Interest}

The authors declare no conflicts of interest regarding the publication of this paper.

\section{References}

[1] Latif, A.F.A. (1984) Lake Nasser-The New Man-Made Lake in Egypt (with Reference to Lake Nubia). In: El-Server, F.B.T., Ed., Ecosystems of the World 32: Lakes and Reservoirs, Elsevier, Amsterdam, 385-416.

[2] Varadharajan, P.D. and Soundarapandian, P. (2014) Effect of Physico-Chemical Parameters on Species Biodiversity with Special Reference to the Phytoplankton from Muthupettai, South East Coast of India. Journal of Earth Science and Climatic Change, 5, 1-10. https://doi.org/10.4172/2157-7617.1000200

[3] Manickam, N.B., Bhavan, P., Santhanam, P., Bhuvaneswari, R., Muralisankar, T., Srinivasan, V., Asaikkutti, A., Rajkumar, G., Udayasuriyan, R. and Karthik, M. (2018) Impact of Seasonal Changes in Zooplankton Biodiversity in Ukkadam Lake, Coimbatore, Tamil Nadu, India, and Potential Future Implications of Climate Change. The Journal of Basic and Applied Zoology, 79, 1-10. 
https://doi.org/10.1186/s41936-018-0029-3

[4] Junk, W.J., Piedade, M.T., Wittmann, F. and Schongart, J. (2011) A Classification of Major Naturally-Occurring Amazonian Lowland Wetlands. Wetlands, 31, 623-640. https://doi.org/10.1007/s13157-011-0190-7

[5] El-Serafy, S.S., Mageed, A.A. and Mola, H.R. (2009) Impact of Flood Water on the Distribution of Zooplankton in the Main Channel of Lake Nasser, Egypt. Journal of the Egyptian Academy of Environmental Development, 10, 121-141.

[6] Holst, I. and Dokulil, M. (1987) Die steuerrndenFaktoren der planktischen Primarproduktion im Stauraum Altenworth ander Donau in Osteerreich. 26 Arbeitstagung der IAD, Passau/Deutschland, Wiss. Kurzreferate, 133-137.

[7] Gophen, M. (2015) The Impact of Turbidity on Zooplankton Densities in Lake Kinneret. Open Journal of Modern Hydrology, 5, 87-94. https://doi.org/10.4236/ojmh.2015.54008

[8] APHA (2005) Standard Methods for Examination of Water and Wastewater. 21st Edition, American Public Health Association (APHA), American Water Works Association (AWWA) and Water Environment Federation (WEF), Washington DC.

[9] Edmondson, W.T. (1966) Freshwater Biology. 2nd Edition, John Wiley and Sons, New York, London, 12248 p.

[10] Rey, J. and Saint-Jean, L. (1969) Les Cladocereres (Crustaces Branchiopodes) du Tchad (Deuxieme Note). Cahiers ORSTOM Series Hydrobiology, 3, 21-42.

[11] Ruttner-Kolisko, A. (1974) Planktonic Rotifers. Biology and Taxonomy. Binnengewässer, 26, 1-146.

[12] Pennak, R.W. (1978) Freshwater Invertebrates of the United States. 2nd Edition, John Wiley \& Sons, New York, 803 p.

[13] Edmondson, W.T. and Lill, A.H. (1987) Conochilus in Lake Washington. Hydrobiologia, 147, 157-162. https://doi.org/10.1007/BF00025738

[14] Fernando, C.H., Paggi, J.C. and Rajapaksa, R. (1987) Daphnia in Tropical Low Lands. In: Peters, R.H. and de Bernardi, R., Eds., Memories $1^{\text {st }}$ Italian Hydrobiology, 45, 107-141.

[15] Jeje, C.Y. (1988) A Revision of the Nigerian Species of the Genera Mesocyclops Sars, 1914 and Thermocyclops Kiefer, 1927 (Copepoda: Cyclopoida). Hydrobiologia, 164, 171-184. https://doi.org/10.1007/BF00008457

[16] Shehata, S.M.A., Shehata, K., Hussien, M.M. and Mageed, A.A. (1998) Taxonomy, Population Structure, and Species Diversity of Rotifera in the High Dam Lake. Egyptian Journal of Aquatic Biology and Fisheries, 2, 1-36.

[17] Shehata, S.M.A., Shehata, K., Hussien, M.M. and Mageed, A.A. (1998) Taxonomical and Ecological Studies on Some Zooplankton Species: Ciliata, Rhizopoda, Turbillaria and Crustac of the High Dam Lake. Egyptian Journal of Aquatic Biology and Fisheries, 2, 37-63.

[18] GAFRD (2017) General Authority for Fish Resources Development. Fish Statistics Year Book. 27th Edition, Cairo, 116 p.

[19] Heikal, M.T. and Abdel Bary, M.R. (1999) Stratification Variability and Trophic State along Lake Nasser. Lake 99. Eighth International Conference on the Conservation and Management of Lakes, Copenhagen, 157-168.

[20] Dokulil, M.T. (1994) Environmental Control of Phytoplankton Productivity in Turbulent Turbid Systems. Hydrobiologia, 289, 65-72. https://doi.org/10.1007/978-94-017-2670-2_6 
[21] Brezonik, P.L., Bouchard Jr., R.W., Finlay, J.C., Griffin, C.G., Olmanson, L.G. anderson, J.P., Arnold, W.A. and Hozalski, R. (2019) Color, Chlorophyll a, and Suspended Solids Effects on Secchi Depth in Lakes: Implications for Trophic State Assessment. Ecological Applications, 29, e01871. https://doi.org/10.1002/eap.1871

[22] Gharib, S.M. and Abdel-Halim, A.M. (2006) Spatial Variation of Phytoplankton and Some Physico-Chemical Variables during the Highest Flood Season in Lake Nasser (Egypt). Egyptian Journal of Aquatic Research, 32, 246-263.

[23] Agarwal, N.K. and Thapliyal, B.L. (2005) Pre-Impoundment Hydrological Study of Bhilangana River from Tehri Dam Reservoir Area in Uttaranchal. Environmental Geochemistry, 8, 143-148.

[24] Farhat, H.F. and Salem, G.S. (2015) Effect of Flooding on Distribution and Mode of Transportation of Lake Nasser Sediments, Egypt. Egyptian Journal of Aquatic Research, 41, 165-176. https://doi.org/10.1016/j.ejar.2015.03.009

[25] Rugner, H., Schwientek, M., Beckingham, B., Kuch, B. and Grathwohl, P. (2013) Turbidity as a Proxy for Total Suspended Solids (TSS) and Particle Facilitated Pollutant Transport in Catchments. Environmental Earth Sciences, 69, 373-380. https://doi.org/10.1007/s12665-013-2307-1

[26] Sagar, P.M. (1986) The Effects of Floods on the Invertebrate Fauna of a Large, Unstable Braided River. New Zealand Journal of Marine and Freshwater Research, 20, 37-46. https://doi.org/10.1080/00288330.1986.9516127

[27] Chen, M. and Chen, F. (2017) Effect of Suspended Solids on Interaction between Filter-Feeding Fish Aristichthys nobilis and Zooplankton in a Shallow Lake Using a Mesocosm Experiment. Journal of Freshwater Ecology, 32, 219-227. https://doi.org/10.1080/02705060.2016.1262293

[28] Gloss, S.P. (1977) Application of the Nutrient Loading Concept to Lake Powell, the Effects of Nutrient Perturbations on Phytoplankton Productivity, and Levels of Nitrogen and Phosphorus in the Reservoir. PhD Thesis, University of New Mexico, Albuquerque, $225 \mathrm{p}$.

[29] Carlson, R.E. (1977) A Trophic State Index for Lakes. Limnology and Oceanography, 22, 361-369. https://doi.org/10.4319/lo.1977.22.2.0361

[30] Utete, B., Zenda, S., Mbauya, W.A. and Tsamba, J. (2017) Plankton and Macroinvertebrate Community Composition in the Pelagic and Non-Vegetated Littoral Drawdown Zones of a Shallow Reservoir, Manjirenji, Zimbabwe. Applied Ecology and Environmental Research, 15, 743-766.

https://doi.org/10.15666/aeer/1501_743766

[31] Matsuzaki, S.S., Suzuki, K., Kadoya, T., Nakagawa, N. and Takamura, N. (2018) Bottom-Up Linkages between Primary Production, Zooplankton, and Fish in a Shallow, Hypereutrophic Lake. Ecology, 99, 2025-2036.

https://doi.org/10.1002/ecy.2414

[32] Sun, X., Chai, Y., Mwagona, P., Shabani, I.E., Hou, W.J. and Li, X.Y. (2019) Seasonal Variations of Zooplankton Functional Groups and Relationship with Environmental Factors in a Eutrophic Reservoir from Cold Region. Applied Ecology and Environmental Research, 17, 7727-7740.

https://doi.org/10.15666/aeer/1704_77277740

[33] El-Shabrawy, G.M. and Dumont, H.J. (2003) Spatial and Seasonal Variation of the Zooplankton in the Coastal Zone and Main Khors of Lake Nasser (Egypt). Hydrobiologia, 491, 119-132. https://doi.org/10.1023/A:1024466216214

[34] Mageed, A.A. and Heikal, M.T. (2005) Water Quality and Zooplankton Dynamics in Lake Nasser, Egypt. Egyptian Journal of Aquatic Biology and Fisheries, 9, 1-24. 
[35] Amaral, J.H., Borges, A., Melack, J., Sarmento, H., Barbosa, P.M., Kasper, D., de Melo, M.L., Fex, D., Wolf, D., da Silva, J.S. and Forsberg, B.R. (2018) Influence of Plankton Metabolism and Mixing Depth on $\mathrm{CO}_{2}$ Dynamics in an Amazon Floodplain Lake. Science of the Total Environment, 630, 1381-1393. https://doi.org/10.1016/j.scitotenv.2018.02.331

[36] Heikal, M.T. (2010) Impact of Water Level Fluctuation on Water Quality and Trophic State of Lake Nasser and Its Khors, Egypt. Egyptian Journal of Aquatic Biology and Fisheries, 14, 75-86. https://doi.org/10.21608/ejabf.2010.2054

[37] Van Zwieten, P., Béné, C., Kolding, J., Brummett, R. and Valbo-Jørgensen, J. (2011) Review of Tropical Reservoirs and Their Fisheries-The Cases of Lake Nasser, Lake Volta and Indo-Gangetic Basin Reservoirs. FAO Fisheries and Aquaculture Technical Paper No. 557. FAO, Rome, 148 p.

[38] Khalifa, N., El-Damhogy, K.A., Fishar, M.R., Nasef, A.M. and Hegab, M.H. (2015) Using Zooplankton in Some Environmental Biotic Indices to Assess the Water Quality of Lake Nasser, Egypt. International Journal of Fisheries and Aquatic Studies, 2, 281-289.

[39] Zhou, J., Qin, B. and Han, X. (2018) The Synergetic Effects of Turbulence and Turbidity on the Zooplankton Community Structure in Large, Shallow Lake Taihu. Environmental Science and Pollution Research, 25, 1168-1175. https://doi.org/10.1007/s11356-017-0262-1

[40] Hussian, A.M., Napiórkowska-Krzebietke, A., Toufeek, M.E. and Abd El-Monem, A.M. (2015) Phytoplankton Response to Changes of Physicochemical Variables in Lake Nasser, Egypt. Journal of Elementology, 20, 855-871. https://doi.org/10.5601/jelem.2015.20.1.895

[41] Dhanasekaran, M., Bhavan, S., Manickam, N. and Kalpana, R. (2017) Physicochemical Characteristics and Zooplankton Diversity in a Perennial Lake at Dharmapuri (Tamil Nadu, India). Journal of Entomology and Zoology Studies, 5, 285-292.

[42] El-Enany, H.R. (2009) Ecological Studies on Planktonic and Epiphytic Microinvertebrates in Lake Nasser, Egypt. PhD Thesis, Zoology Department, Faculty of Science, University of Benha, Benha, 311 p.

[43] Mageed, A.A., Abdel-Rahman, H.S., Heikal, M.T., Salem, T.A. and Salama, E. (2008) Response of Plankton Prevalence to Water Quality Variables in Lake Nasser during Turnover Period. Egyptian Journal of Aquatic Research, 34, 217-231.

[44] Kang, H.K. (2012) Effects of Suspended Sediments on Reproductive Responses of Paracalanus sp. (Copepoda: Calanoida) in the Laboratory. Journal of Plankton Research, 34, 626-635. https://doi.org/10.1093/plankt/fbs033 